\title{
SISTEM SAPAAN DALAM WAYANG KULIT
}

\author{
oleh Endang Nurhayati \\ FBS Universitas Negeri Yogyakarta
}

\begin{abstract}
This article is about a research study conducted to describe the system, type, and function of form of address in wayang kulit, the Javanese leather-puppet shadow play. The subject under study was a recording of such a play titled Karna Tandhing performed by Timbul Hadiprayitna as the puppet master. The research method applied was descriptive in nature. The research data were obtained by means of a listen-and-write technique and analyzed by means of contextual interpretation.

The research results are as follows. 1. The system of form of address in wayang kulit consists of aspects of (1) relation between the addresser and addressee, (2) sex/gender, (3) setting (place, time, and atmosphere), (4) purpose, (5) honoring, (6) doer, vocation, or profession, (7) marriage and love, (8) mention of dwelling place, (9) religion and belief, (10) use of pronoun, (11) zero, and (12) mention of specific identity. In type, the form of address can be, among others, (1) a pronoun, (2) a proper name: a pre-adult name, an alternative name, or dasanama, (3) a title attributed due to position of authority, (4) a name others use to call one, (5) a hereditary form of address, (6) paraban 'a name given due to intimacy', (7) poyokan 'a derogatory or mocking name', (8) a profession, (9) a doer of an act, (10) an expression of fondness, (11) an expression of being proud of one, (12) an expression of friendship, (13) an expression of displeasure, annoyance, or anger, (14) an expression in self-introduction, (15) an expression for peprenahan/ mbasakke 'showing how one is related to the other by blood, age, etc.', (16) an expression related to where one dwells, (17) an expression related to position of authority, (18) an expression in honoring, (19) an expression used due to marriage: adult name, husband's name, name of first child, (20) a form of address used when addressing a god, goddess, or God, (21) a form of address for the wife of a king, (22) a form of address of zero nature, (23) an expression of cursing, (24) a form of address of specific nature, (25) a noun plus $m u, e$, or $n e,(26)$ a noun, (27) a noun plus $k u,(28)$ a form of address related to religion, (29) a form of address related to kinship plus $e$ or $n e,(30)$ a form of address used falsely/in playacting/pretence, and (31) a form address to point one out. In function, the form of address can be (1) honorific, i.e., to honor one, (2) to call out to one, (3) to call one with an attribute, (4) mbasakke 'to show how one is related to the other by blood, age, etc., (5) to mock the other, (6) to show intimacy/to make intimate, (7) to show one's place of origin, (8) to introduce oneself, (9) to build a certain atmosphere, (10) to be sarcastic, (11) to clarify one's identity, (12) to be used falsely in dramatization or in a play or in pretence, and (13) to make a comic effect.
\end{abstract}

Keywords: form of address, wayang kulit, system, type, function 


\section{A. PENDAHULUAN}

Dalam kehidupan sehari-harinya manusia selalu menggunakan bahasa untuk memenuhi berbagai kebutuhannya. Tanpa bahasa manusia akan mengalami kesulitan dalam beraktifitas. Oleh karena betapa pentingnya bahasa dalam kehidupan manusia, maka Kartomihardjo (1988:1) menjelaskan bahwa bahasa tidak dapat dipisahkan dari kehidupan manusia. Tanpa bahasa manusia tidak dapat berkomunikasi dengan manusia lain, tidak dapat menyatakan perasaan, tidak dapat menyapa, tidak dapat berpikir dan lain sebagainya.

Tannen (1996:14) mengatakan bahwa hidup adalah perkara menghadapi orang lain, baik itu dalam hal yang sangat penting ataupun dalam hal yang sepele, misalnya berbasa-basi. Crystal (1980:264) menyebut basa-basi dengan istilah fungsi fatis atau phatic function. Fungsi fatis adalah fungsi bahasa yang cenderung digunakan sebagai sarana kontak sosial daripada untuk bertukar informasi atau menyatakan ide. Bentu-bentuk kegiatan seperti salam, sapaan, panggilan atau memanggil merupakan suatu kegiatan yang menimbulkan kontak sosial, sehingga bentuk-bentuk semacam ini termasuk dalam fungsi fatis. Pernyataan Crystal tersebut sejalan dengan penjelasan Malinowski (dalam Kartomihardjo, 1988:27 dan Alwasilah, 1985:28) yang menyatakan bahwa salam, dan sapaan termasuk ke dalam fungsi fatis atau phatic communication.

Dalam wayang kulit fungsi fatik belum banyak dikaji. Untuk itu ada peluang mengkaji sitem sapaan dalam wayang kulit. Adapun hal yang mendorong untuk meneliti hal tersebut adalah (1) belum ada penelitian terhadap permasalahan tersebut; (2) sistem sapaan ini merupakan bagian dari salah satu jenis pertimbangan penentuan bentuk sapaan dalam masyarakat Jawa yaitu fungsi dan tujuan; (3) meskipun berkonsentrasi pada bagian kecil yaitu fungsi dan tujuan mempertimbangkan pemilihan bentuk sapaan, tetapi justru di dalamnya muncul banyak sistem yang tidak digunakan dalam kehidupan sehari-hari masyarakat Jawa.

Sistem sapaan di dalam wayang kulit menunjukkan gejala yang lebih bervariasi dibanding dengan sapaan dalam masyarakat Jawa masa kini. Spesifikasi sistem terlihat pada fungsi dan kekhasan bentuk Sebagai contoh, munculnya sapaan terhadap Dewa, guru, pejabat tertentu, abdi, golongan masyarakat tertentu dan lain sebagainya.

Fenomena ini akan dikaji dengan judul Sistem Sapaan dalam Wayang Kulit. Hasil penelitian diharapkan dapat melengkapi teori sapaan dalam masyarakat Jawa yang telah ada dan teori komunikasi secara umum.

Berdasarkan uraian latar belakang dan tujuan yang diharapkan, maka dapat dibuat rumusan masalah sebagai berikut.

1. Bagaimanakah sistem sapaan yang digunakan di dalam wayang kulit?

2. Bagaimanakah bentuk sapaan yang digunakan?

3. Seperti apakah fungsi sapaan dalam wayang kulit?

Sesuai dengan rumusan masalah di atas, penelitian ini bertujuan untuk mendeskripsikan:

1. sistem sapaan yang digunakan di dalam wayang kulit,

2. jenis atau bentuk sapaan yang digunakan di dalam wayang kulit, dan

3. fungsi sapaan yang digunakan di dalam wayang kulit.

Wayang berasal dari akar kata yang yang berarti bayangan. Mayang berarti memainkan bayangan atau pertunjukan bayangan (Mulyono, 1989:51). Pergelaran wayang kulit merupakan salah satu karya seni dan karya sastra yang amat digemari masyarakat. Hal ini disebabkan oleh pandangan bahwa wayang dipandang sebagai suatu bahasa simbol dari hidup dan kehidupan yang lebih bersifat rokhaniah dari pada hidup lahiriah (Sri Mulyono, 1989:15). Apabila seseorang melihat wayang, bukan wayang itu yang dilihat, tetapi lakon atau bayangan diri kita yang seolah-olah masuk dalam lakon tersebut. Hal ini dapat 
dirasakan, saat kita menonton wayang, kita dapat mengoreksi perilaku dan sifat kita lewat tokoh yang mirip dengan kharakter kita atau penonton-penonton yang lain Dengan fenomena tersebut setiap penonton secara sadar dapat melihat bayangan dirinya dalam tokohtokoh cerita tersebut.

Berdasarkan uraian tersebut, dapat dilihat bahwa aspek utama yang akan dimainkan dalang adalah permainan komunikasi. Komunikasi yang terjadi adalah kommunikasi antartokoh yang diceritakan, komunikasi dalang dengan krunya, komunikasi dalang dengan penontonya, atau juga komunikasi tokoh cerita dengan penonton, dan komunikasi cerita dengan penonton. Sistem komunikasi dalam pakeliran tidak jauh berbeda dengan yang terjadi dalam sistem komunikasi masyarakat Jawa, tetapi dalam hal pemilihan sapaan variasi dalam wayang justru lebih beragam.

Pemilihan bentuk sapaan, panggilan, dan sebutan berkaitan erat dengan martabat seseorang. Orang akan merasa 'diorangkan' jika disapa sesuai dengan stratanya. Oleh karena itu sapaan, panggilan, dan sebutan merupakan salah satu penanda strata sosial yang berkaitan dengan derajat dan martabat seseorang. Orang akan merasa terhina seandainya disapa dengan poyokan, dalam suasana yang resmi, dan akan merasa gembira atau tersipu malu jika hal tersebut disampaikan dalam suasana santai. Oleh karena itu pemilihan bentuk sapaan yang tepat memiliki peranan penting dalam upaya menggambarkan siapa tokoh tersebut.

Sapaan adalah morfem, kata, atau frasa yang dipilih untuk menyatakan hubungan antara penutur dengan mitra tutur dalam suatu percakapan (Kridalaksana, 1984:171). Dalam interaksi sosial, sapaan digunakan secara langsung antara penutur dan mitra tutur (Crystal, 1980:13). Agar tidak terjadi ketegangan interaksi, maka pemilihan bentuk sapaan yang tepat harus dipertimbangkan. Apakah seseorang harus menyapa dengan nama diri (first name), dengan gelar, ataukah cukup panggilan akrab saja.
Chaika (1982:45-52) membedakan antara sapaan atau address dengan panggilan atau summons, dan salam atau greettings. Sapaan adalah bagian dari salam yang selalu mengandung kekuasaan. Kekuasaan yang dimaksud adalah bahwa sapaan adalah penanda jatidiri dari penutur. Semakin tinggi tingkat sosial seseorang yang disapa, semakin formal sapaan yang dipergunakan. Seseorang tidak akan berani njangkar atau menyapa dengan panggilan akrabnya saja terhadap orang yang lebih tinggi derajatnya.

Aspek di luar kebahasaan yang sangat menentukan pemilihan sapaan adalah faktor sosial. Faktor tersebut misalnya: umur, derajat atau keturunan, jenis kelamin, kekerabatan atau $a w u$, tingkat keformalan, dan status perkawinan (Wijana, 1991:2).

Macam-macam atau jenis sapaan dalam bahasa Indonesia dibagi menjdi 9 yaitu (1) kata ganti seperti aku, kamu, engkau, dia dan lain-lainnya; (2) nama diri seperti atau nama orang/ penutur/ mitra tutur; (3) istilah kekerabatan, seperti ayah, ibu, nenek, anak dan lain-lainnya; (4) gelar dan pangkat seperti dokter, insinyur, guru, jendral; (5) kata pelaku seperti pembaca, pendengar; (6) bentuk nomina + ku, seperti Tuhanku, kekasihku; (7) kata-kata deiksis atau penunjuk, seperti sini, situ, ini; (8) nominal seperti tuan, nyonya, Yang Mulia; dan (9) zero atau nol, seperti pertanyaan Mau kemana? Di dalam kalimat ini terdapat sapaan bisa saudara, kamu engkau, ibu dan lain sebagainya (Kridalaksana, 1982:14-15).

Wijana (1991) mengklasifikasikan sapaan menjadi tujuh kategori yaitu (1) sapaan yang berupa kata ganti, (2) sapaan kekerabatan, (3) sapaan pekerjaan, (4) sapaan nama diri, (5)sapaan yang berhubungan dengan kasih, sayang dan manis, (6) sapaan yang berkaitan dengan agama, dan (7) sapaan persahabatan.

Kategori sapaan di atas memiliki kesamaan dengan sapaan dalam masyarakat Jawa. Berikut ini adalah sapaan dalam bahasa Jawa (Jawa Timur) seperti yang dijelaskan oleh Supriyanto (1986) merinci jenis sapaan bahasa Jawa Jawa Timur menjadi (1) sapaan yang berupa kata ganti, (2) sapaan yang berupa nama: 
kecil, poyokan, paraban, nama tua atau nama setelah menikah, nama suami, nama anaknya, (3) sapaan karena pangkat, dan jabatan, (4) sapaan kekerabatan, (5) sapaan kekerabatan + $e / n e$, dan kata benda.

Berdasarkan jenis sapaan tersebut di atas dapat dipahami bahwa jenis sapaan menentukan sekali pemilihan bentuk sapaan yang tepat. Pemilihan sapaan menunjukkan pula betapa pentingnya sapaan terhadap jatidiri seseorang. Oleh karena itu dapat dikatakan bahwa di dalam sapaan terkandung power atau kekuasaan untuk sapaan terhadap strata sosial tinggi dan terkandung solidarity atau kebersamaan dan keakraban untuk jenis sapaan seperti paraban dan njangkar 'memanggil nama diri'.

Kekuasaan sapaan dapat ditentukan oleh status sosial, usia, hubungan kerja seperti atasan dan bawahan, jenis kelamin dan lain sebagainya. Semakin besar kekuasaan seseorang akan menyebabkan semakin jauh perbedaan jarak sosialnya. Interaksi yang terjadi seperti dalam pola tersebut dinamakan interaksi vertikal. Selain interaksi vertikal ada juga interaksi yang disebut dengan istilah horisontal. Interaksi horisontal adalah interaksi yang menandai jarak sosial antara penutur dan mitra tutur sangat dekat, sehingga sapaan yang digunakan memiliki rasa kebersamaan atau sederajat dan akrab.

Berdasarkan unsur kekuasaan dan kebersamaan di dalam sapaan, maka pemilihan bentuk sapaan sangat dipengaruhi oleh unsur konteks pembicaraan. Konteks pembicaraan yang mempengaruhi ketepatan pemilihan sapaan antara lain berupa medan wacana, pelibat wacana, dan sarana wacana (Halliday, 1985, dalam terjemahan Barori Tou, 1994:16). Pelibat wacana merujuk pada kondisi atau strata sosial orang yang terlibat di dalam pembicaraan. Medan wacana merujuk pada suasana yang terjadi dalam pembicaraan dan apa yang sedang dibicarakan. Adapun sarana wacana merujuk pada bahasa yang digunakan dalam proses percakapan.

Pemilihan sapaan selain ditentukan oleh konteks pembicaraan, dipengaruhi pula oleh kaidah sapaan. Kaidah sapaan dapat di golongkan menjadi dua yaitu alternasi dan kookurensi. Kaidah alternasi bersifat paradigmatik, yaitu kaidah yang berkenaan dengan cara menyapa, dan cara memilih unsurunsur leksikal yang disesuaikan dengan ciri-ciri orang yang disapa, hubungan penutur dengan mitra tutur, dan situasi yang melatarinya. Kaidah kookurensi adalah kaidah yang berkaitan dengan kesertaan bentuk sapaan dengan bentuk yang lain. Misalnya penggunaan kata tertentu yang disesuaikan dengan situasi dan kedudukan orang yang disapa. Kaidah yang demikian ini adalah kaidah yang bersifat sintagmatik (Ervin Tripp, 1972:213).

Uraian tersebutlah yang melandasi penataan pola atau sistem sapaan dalam wayang kulit, mengingat sistem komunikasi dalam pergelaran wayang kulit dengan pola komunikasi nyata memiliki kemiripan. Oleh karena itu rambu-rambu teori tersebut dapat dijadikan kerangka pikir untuk mengenali data yang ditemukan.

\section{B. METODE PENELITIAN}

Subjek penelitian adalah rekaman pergelaran wayang kulit gaya Yogyakarta, oleh dalang Ki Timbul Hadiprayitna dari Patalan Bantul, dengan lakon atau cerita Karna Tandhing. Rekaman cerita Karna Tandhing terdiri dari 8 kaset, masing-masing berdurasi 60 menit dalam side A dan B durasi masing-masing 30 menit. Pergelaran dilakukan oleh dalang Ki Timbul Hadiprayitna dari Patalan Bantul dibantu para pengrawit yang terdiri dari penabuh, wiraswara, dan waranggana: Nyi Painah, Nyi yatinah, Nyi Sri Rahayu, dan Nyi Kalimah. Identitas rekaman/ kaset: kaset direkam oleh Bintang Fajar tahun 1983, dengan ijin perindustrian: 200/Jateng/01/BIN IK/IV/83 IK: 2300.00 .00 ISIC:3900, terdaftar no.: 175585. Data penelitian berupa bentuk-bentuk sapaan dan konteksnya.

Pengumpulan data dilakukan dengan teknik simak dan catat. Rekaman disimak dengan cermat dan berulang-ulang, dicatat pola sapaannya dan dicatat sesuai tipe sistem masing-masing. Setelah data tertata kemudian 
dilakukan analisis, dan hasinya dipaparkan secara deskriptif.

Metode penelitian adalah metode deskriptif kualitatif. Analisis dilakukan dengan pemaknaan secara kontekstual. Maksudnya pendeskripsian atau pemaparan hasil berdasarkan fakta dengan pertimbangan konteks tuturan yang melatari terjadinya tuturan, konteks sosial dan kultural.

\section{HA S I L P E N E L I T I A N D A N PEMBAHASAN}

\section{Hasil Penelitian}

Hasil penelitian tentang Sistem Sapaan Dalam Wayang Kulit dalam Lakon Karna Tandhing dapat dipaparkan sebagai berikut.

\section{a. Sistem Sapaan}

Sistem sapaan dalam wayang kulit terbentuk oleh beberapa aspek penentu seperti berikut: (1) aspek hubungan antara penyapa dan tersapa, (2) aspek jenis kelamin, (3) aspek setting (tempat, waktu, dan suasana), (4) aspek tujuan, (5) penghormatan, (6) aspek pelaku, pekerjaan atau profesi, (7) aspek perkawinan dan cinta, (8) aspek penyebutan tempat tinggal, (9) aspek agama dan kepercayaan, (10) aspek penggunaan kata ganti, (11) aspek zero, dan (12) aspek penyebutan identitas khas.

Sistem sapaan yang ditentukan oleh hubungan antara penyapa dan tersapa memiliki beberapa pola hubungan seperti berikut ini. (1) Pola hubungan kekerabatan atau darah yang dalam bahasa Jawa disebut $a w u$. Hubungan ini ada yang bersifat vertikal dan horisontal, (2) tingkat keakraban, (3) hubungan persahabatan, dan (4) hubungan kerja: majikan dan bawahan.

\section{b. Jenis Sapaan}

Bentuk atau jenis sapaan dalam wayang kulit adalah sebagai berikut: (1) sapaan jenis kata ganti, (2) nama diri: nama kecil, nama alternatif atau dasanama, (3) gelar atas kedudukan, (4) sebutan atau panggilan, (5) sapaan keturunan, (6) paraban 'nama keakraban', (7) poyokan 'nama untuk meremehkan/ meledek', (8) sapaan profesi, (9) sapaan pelaku, (10) sapaan kasih sayang, (11) sapaan kebanggaan, (12) sapaan persahabatan, (13) sapaan ketidak sukaan/ jengkel, marah, (14) sapaan perkenalan, (15) sapaan peprenahan/ mbasakke, (16) sapaan yang berhubungan dengan tempat tinggal, (17) sapaan jabatan, (18) sapaan penghormatan, (19) sapaan karena hubungan perkawinan: nama tua, nama suami, nama anaknya (pertama), (20) sapaan untuk Dewa, Dewi dan Tuhan, (21) sapaan untuk permasuri, (22) sapaan zero, (23) sapaan dalam umpatan, (24) sapaan sebutan khas, (25) sapaan dalam nomina + mu, e, ne, (26) sapaan nominal, (27) sapaan nominal $+\mathrm{ku}$, (28) sapaan yang berkaitan dengan agama, (29) sapaan sebutan kekerabatan + e, ne, (30) sapaan semu/ sandiwara dan (31) sapaan penunjuk.

\section{c. Fungsi Sapaan}

Sapaan dalam wayang kulit memiliki beberapa fungsi seperti berikut ini. (1) Sapaan yang berfungsi untuk menghormat atau honorifik, (2) sapaan untuk memanggil, (3) sapaan untuk menyebut, (4) sapaan untuk mbasakke, (5) sapaan untuk meledek, (6) sapaan untuk keakraban/ mengakrabkan, (7) sapaan untuk menunjukkan asal, (8) sapaan untuk berkenalan, (9) sapaan untuk menciptakan suasana tertentu, (10) sapaan untuk menyindir, (11) sapaan untuk menjelaskan jati diri, (12) sapaan semu untuk bermain drama (dalam sandiwara), dan (13) sapaan untuk melucu.

\section{Pembahasan}

Seperti yang telah diuraikan pada hasil penelitian, bahwa sistem sapaan dalam wayang kulit memiliki 12 aspek penentu sistem, 31 jenis, dan 13 fungsi. Pembahasan hasil penelitian tersebut dapat diringkas seperti uraian berikut.

\section{a. Sistem dan Fungsi Sapaan yang Ditentukan oleh Aspek Hubungan Antara Penyapa dengan Tersapa}

Sistem ini memiliki beberapa pola hubungan, yang pertama pola hubungan kekerabatan atau hubungan darah, atau 
perkawinan. Pola ini dalam masyarakat Jawa disebut peprenahan awu. Hubungan darah memiliki alur ke atas dari ego dan alur ke bawah atau bisa disebut vertikal dan horisontal dari ego. Alur kekerabatan vertikal dalam masyarakat Jawa ada tujuh tingkatan atau pitung turunan: anak, bapak, simbah, simbah buyut, simbah canggah, simbah wareng, simbah udheg-udheg, simbah gantung siwur. Apabila dihitung sampai sepuluh tingkat ditambah: simbah gropak senthe, debok bosok, dan galih asem (Tashadi, 1983:24). Alur ini memiliki kesamaan dengan alur ke bawah. Perbedaannya pada alur ke bawah sebutan simbah'nenek' diubah putu 'cucu'. Sistem sapaan yang menganut aspek tingkatan alur kekerabatan vertikal di dalam penelitian ini hanya ditemukan dua tingkat alur ke atas dari ego dan dua tingkat ke bawah dari ego. Berikut ini adalah kutipan masing-masing tingkat.

(1) Duryudana: Rama Prabu Mandaraka, dereng dangu rawuh wonten pakuwon Sewuntana..

Duryudana: 'Ayah Prabu Mandaraka, belum lama datang di perkemahan Sewuntana..'

(2) Janaka: Panahe digawa bapakmu.

Janaka: 'Panahnya dibawa bapakmu.'

Gareng: Panahe ndara nang ngendi Ma?

Gareng: 'Panahnya ndara'tuan' di mana Pak?'

Gareng: Kyaine ki nek nggawa panah senengengeri-ngeri.

Gareng: 'Bapak itu kalau membawa panah sukanya ngeri-ngeri'jalan lambat di belakang'.

Contoh (1) adalah sapaan Duryudana terhadap ayah mertuanya yaitu Prabu Mandaraka. Sapaan rama merupakan sapaan ke atas satu tingkat dari ego. Ego menyapa mertua dengan pilihan kata sapaan rama bukan bapak, karena orang yang disapa memiliki kedudukan tinggi yaitu raja atau prabu, sehingga kata saapan dipilih yang menghormat atau honorifik. Berikutnya pada contoh (2) Janaka menyebut ayah Gareng dengan kata sebutan bapakmu, sebutan ini merupakan sebutan biasa terhadap orang yang berstrata biasa atau mungkin lebih rendah. Janaka berstrata lebih tinggi karena dia adalah majikan sehingga punya kekuasaan memilih jenis sapaan yang dimaui. Meskipun demikian Janaka tidak akan memilih kata keng rama' ayahandamu' kepada Gareng, kecuali Janaka punya maksud tertentu misalnya menyindir atau justru sedang marah, pilihan itu bisa saja terjadi, tetapi tidak pada suasana wajar. Pada contoh (2) Gareng menyapa ayahnya dengan sebutan $m a$ 'pak'. Ma merupakan penggalan dari kata rama. Meskipun Gareng memilih jenis sapaan $M a$ bukan berarti dalam sapaan ini terdapat unsur honorifik seperti yang terjadi pada contoh (1) yaitu penghormatan anak kepada ayahnya. Sapaan ini merupakan sapaan akrab para abdi atau panakawan terhadap ayahnya. Secara konteks sosial pemilihan bentuk penggal atau wancah menandai bahwa hubungan komunikasi terjadi secara biasa atau tidak menghormat. Kategori kata penggal merupakan penanda tingkat tutur madya. Berkomunikasi dengan tingkat tutur madya memunjukkan bahwa di dalam komunikasi tersebut terjadi hubungan biasa saja. Berikut ini adalah kutipan sapaan alur vertikal ke atas dua tingkat dari ego atau tingkatan nenek atau kakek.

(3) Maswapati: Putuku Srikandhi kowe raharja?

Maswapati: 'Cucuku Srikandhi kamu selamat?'

Srikandhi: Nuwun inggih pangestunipun eyang Prabu mboten manggih sambekala.

Srikandhi: 'Iya atas doa restu kakek Prabu tidak ada halangan.'

Pada contoh (3) sapaan Srikandhi terhadap raja Maswapati memilih jenis sapaan honorifik. Sapaan yang biasa digunakan terhadap kakek, dalam masyarakat kecil istilahnya simbah/ simbah kakung 'kakek'. Sapaan ini tidak pas jika dipilih untuk sapaan atau sebutan terhadap orang berstrata raja. Dalam contoh (3) sapaan Raja Maswapati kepada Srikandhi, merupakan sistem sapaan vertikal ke bawah dua tingkat dari ego atau sapaan untuk cucu. Maswapati menyapa Srikandhi dengan sapaan putuku 'cucuku'. 
Sapaan ini merupakan sapaan akrab seorang kakek terhadap cucunya. Berbeda jika cucu yang disapa memiliki strata sosial tinggi seperti raja, sapaan yang digunakan pasti berbeda. Berikut ini kutipannya.

(4) Maswapati: Wayah Prabu Bethara Kresna padha kanthiraharja.

Maswapati: 'Wayah 'cucu' Prabu Bethara Kresna selamat.'

Kutipan (4) sapaan yang digunakan Maswapati adalah sapaan honorifik atau penghormatan. Hal ini dilakukan karena Kresna adalah seorang raja yang berkharisma yaitu titisan Wisnu. Oleh karena itu sebutan raja Kresna adalah bethara 'sebutan dewa'. Sapaan kekerabatan alur vertikal ke bawah berikutnya adalah satu tingkat kebawah dari ego yaitu sebutan untuk anak. Perhatikan kutipan berikut.

(5) Sengkuni: Kawula nuknun, nuknun inggih dahat dupi nampi pangandika dalem anak Prabu rumentah abdi dalem pun bapa.

Sengkuni: 'Daulat, siap menerima perintah ananda Prabu yang diperintahkan kepada hambamu yaitu bapak anda.'

Dalam kutipan (5) sapaan Sengkuni terhadap Duryudana memilih kata pangandika dalem anak Prabu ' perintahmu ananda Prabu' dengan tujuan untuk menghormat atau sapaan tersebut adalah honorifik. Seorang abdi raja selalu menjunjung tinggi terhadap raja sehingga segala ucapan harus bersifat menghormat. Berbeda jika Sengkuni menyapa kemenakan yang lain seperti pada kutipan berikut ini.

(6) Sengkuni: Jaya Wikatha, Wikathabala, anane kowe tak timbali maju ngger, panuwunmu natkala dina kang wis kepungkur iki mau bisa tak aturake anak Prabu.

Sengkuni: 'Jaya Wikatha, Wikathabala, adapun kamu aku panggil mehadap nak, permintaanmu beberapa waktu yang lalu ini tadi bisa aku sampaikan kepada ananda Prabu.'

Sapaan Sengkuni terhadap Jaya Wikatha dan Wikathabala menggunakan sapaan biasa saja tanpa ada hormat bahkan
Sengkuni menyapa dengan njangkar 'langsung menyebut nama' dan menyebut dengan kata ganti kowe 'kamu' yang menurut konteks sosial Jawa kata kowe bernuansa makna agak remeh. Selain sistem vertikal ada sistem horisontal, seperti berikut ini.

(7) Duryudana: Kaka Adipati Karna, raharja rawuhipun kaka Adipati.

Duryudana: 'Kanda Adipati Karna, selamat datangmu kanda Adipati.'

Duryudana: Kartamarma, prayogakna jeneng para ngadhep ngarsane raka para.' Duryudana: 'Kartamarma, santai sajalah kamu menhadap Kakamu.'

Kutipan (7) adalah sapaan Duryudana terhadap Adipati Karna yang berstatus lebih tua sehingga disapa dengan sapaan kakak. Disamping sapaan di atas, yaitu sapaan horisontal untuk laki-laki, ada pula sapaan horisontal untuk wanita. Jenis sapaan horisontal untuk wanita berbeda bentuk jika dibandingkan dengan sapaan horisontal terhadap laki-laki. Perhatikan kutipan berikut ini.

(8) Banowati: Kadangipun kakang dhimas Dursasana, durung suwe kowe ngadhep ana ngarsane pun kakang padha basuki Dursasana.

Banowat: 'Saudara kakak dinda Dursasana, belum lama kamu menghadap di hadapan kakanda selamat Dursasana.'

Dursasana: Nuwun pangestunipun kakangmbok ratu mboten manggih sambekala. Pangabekti kula konjuk sahandhaping pepada kakangmbok.

Dursasana: 'Iya atas doa restu kanda ratu tidak mendapat alangan. Baktiku aku letakkan di bawah telapak kaki kakanda.'

Kutipan (8) adalah jenis sapaan horisontal terhadap kakak wanita dan adik lakilaki. Banowati menyapa adik iparnya yaitu Dursasana dengan pilihan jenis sapaan yang relatif lebih bebas jika dibanding dengan pilihan sistem sapaan bagi Dursasana terhadap Banowati. Banowati secara strata sosial berkedudukan sebagai permaisuri raja, maka dia memiliki kebebasan menyapa dengan pilihan tingkat tutur apapun. Oleh karena itu 
pada kutipan di atas, Banowati bisa menyapa dengan sebutan kehormatan dhimas, menyapa dengan kata ganti yang agak kasar yaitu kowe, dan dia juga dapat menyapa dengan nama diri saja atau njangkar. Dhimas adalah jenis sapaan penghormatan. Dursasana pantas disapa dengan sapaan hormat dhimas karena dia seorang pangeran.

Berbeda dengan konteks sosial di atas, Dursasana ketika menyapa Banowati dia harus menggunakan sapaan honorifik yaitu kakangmbok, dan tidak bisa memakai kata mbakyu, atau yu saja. Adapun aspek penyebab hal tersebut adalah konteks strata sosial Dursasana lebih rendah daripada Banowati. Selain sapaan tersebut ada sapaan lain yaitu mbasakke, seperti kutipan berikut ini.

(9) Gareng: Truk gandheng Bagong mati, nek si Inem kae njur dadi mbakyumu piye?

Gareng: 'Truk karena Bagong meninggal, bagaimana jika si Inem jadi kakakmu?

Sebutan mbakyu pada kutipan (9) merupakan sapaan mbasakke, yaitu Gareng mbasakke Petruk terhadap Inem yang akan diambil isteri. Petruk akan menyapa dengan sapaan mbakyu jika si Inem betul jadi isteri Gareng.

Sistem sapaan berikutnya adalah sistem sapaan yang ditentukan oleh aspek hubungan penyapa dan tersapa pada pola tingkat keakraban. Pada pola ini jenis sapaan yang dipilih didasarkan pada tingkat keakraban hubungan antara penyapa dengan yang disapa. Semakin dihormati orang yang disapa maka sapaan yang dipilih penyapa semakin tinggi tingkat penghormatannya. Pilihan tingkat tutur akan dipilih tingkat tutur krama inggil dan ditambah sebutan honorifik. Adapun sapaan pada tingkat sosial yang setara pilihan sapaan jatuh pada jenis biasa saja. Tingkat tutur yang dipilih dalam bisa tingkat tutur: ngoko, madya ngoko atau krama lugu. Pemilihan tingkat tutur ini bersifat adaptasi, artinya pilihan didasari konteks suasana pertuturan yang terjadi. Dalam tingkat keakraban yang erat bisa dipilih krama jika suasana pertuturan resmi, dan bisa dipilih madya atau ngoko jika suasananya relatif lebih santai. Pola seperti ini dalam wayang kulit bisa dilihat pada kutipan-kutipan berikut.

(10) Banowati: Togog raharja sowanmu Gog. Banowati: 'Togog selamat menghadapmu Gog.'

Togog: Inggih pangestunipun Gusti mboten manggih sambekala.

Togog: 'Iya atas doa restu Gusti tidak mendapat halangan.'

Pada kutipan tersebut penyapa orang yang berstrata sangat tinggi yaitu permasuri dan yang disapa bestrata sosial sangat rendah yaitu abdi. Penyapa pada hubungan itu bebas memilih jenis sapaan, dan yang disapa harus memilih sapaan yang sangat menghormat. Banowati menyapa dengan sebutan nama diri orang yang disapa atau njangkar yaitu Togog, sedangkan Togog menggunakan sapaan honorifik kedudukan yaitu Gusti. Togog tidak bisa memilih jenis sapaan yang lain selain honorifik karena kedudukanya sebagai abdi. Disamping hubungan tersebut ada tingkat hubungan setara atau sederajad dan suasana wajar. Perhatikan kutipan berikut ini.

(11) Janaka: Yen ora sisip panduluku kaya iki kakang Jayawikatha.

Janaka: 'Jika tidak salah penglihatanku ini seperti kakak Jayawikatha.'

Jayawikatha: ora kleru pandugane si adhi. Jayawikatha: 'tidak keliru dugaan adik.'

Pada kutipan (11) hubungan antara Janaka dengan Jayawikatha berpola setara atau relatif tidak membedakan derajat sosial. Mereka sama-sama pangeran keturunan Bharata. Suasana tuturan terjadi pada suasana biasa yaitu pertemuan di jalan/ hutan, dan saat itu masih dalam kondisi wajar yaitu saling menyapa. Janaka menyapa dengan sapan kakang, dan Jayawikatha dengan sapaan adhi. Sapaan kakang dan adhi merupakan tingkat sapaan yang setara dan tidak menunjukkan nuansa menghormat, sehingga sapaan yang demikian masuk dalam sistem hubungan keakraban yang sederajat. Pola hubungan berikutnya adalah pola hubungan persahabatan. Berikut ini adalah pola sapaan persahabatan dengan jenis sapaan menyebut nama diri dan jenis zero. 
(12) Nirbita: Udawa, nangis ki ambakgawean gampang ning angel iki.

Nirbita: 'Udawa, meskipun pekerjaan mudah tetapi sulit ini.'

Udawa: Kejawi nek namung ndrejes niku gampil.

Udawa: 'Kecuali jika hanya meneteskan air mata itu mudah.'

Nirbita: La kuwi rakora nangis kuwi.

Nirbita: 'Itu kan tidak menangis itu.'

Pada kutipan (12) hubungan sosial antara patih Nirbita dan patih Udawa adalah hubungan persabatan. Mereka sama-sama patih, sehingga komukikasi yang dibangun bersifat akrab wajar tidak ada unsur penghormatan dan perendahan. Adapun Udawa memilih tingkat tutur madya krama, secara usia udawa lebih muda. Meskipun demikian suasana komunikasi terbangun wajar, hal ini terlihat pada isi pembicaraan yang begitu santai. Sapaan yang digunakan dalam kutipan (12) adalah sapaan nama diri yaitu Udawa dan sapaan zero yaitu Udawa tidak secara eksplsit menyebut Nirbita dengan pilihan sapaan tertentu misalnya kakang.

\section{b. Sistem dan Fungsi Sapaan yang Ditentukan oleh Aspek Jenis Kelamin}

Jenis kelamin sangat menentukan di dalam seseorang memilih jenis sapaan terhadap orang yang disapa. Jenis sapaan terhadap wanita memiliki ciri khas sebagai penanda gender wanita begitu pula jenis sapaan terhadap pria atau laki-laki. Selain ada bentukbentuk khas penanda jenis kelamin, ada pula jenis sapaan yang berlaku secara umum. Maksudnya bentuk ini dapat digunakan untuk menyapa wanita dan pria. Berikut ini adalah kutipan sistem sapaan yang ditentukan oleh aspek jenis kelamin.

(13) Jayawikatha: Paman, paman Harya ingkang putra nungsung..

Jayawikatha: 'Paman, paman Harya ananda ingin tahu..'

(14) Banowati: Bogadenta mati dening dhimas Janaka?
Banowati: 'Bogadenta mati oleh dhimas Janaka?

(15) Werkudara: Nirbita kakekku. 'Nirbita kakekku.'

(16) Semar: Ah Gus sedaya kalepatanipun anak kula, mugindara paring..

Semar: 'Ah Gus semua kesalahan anakku, semoga tuan memberi..

(17) Kresna: Diajeng Wara Srikandhi enggal kowe..

Kresna: 'Diajeng Wara Srikandhi cepat kamu..'

(19) Srikandhi: Nanging kakang embok Wara Sembadra..

Srikandhi: 'Tetapi kakang embok Wara Sembadra.

Sapaan yang digunakan dalam kutipan (13) sampai (16) yaitu paman, dhimas, kakekku, dan gus adalah jenis sapaan yang ditandai oleh aspek hubungan jenis kelamin laki-laki, sedangkan pada kutipan (17) dan (19) adalah sapaan yang ditandai oleh aspek hubungan jenis kelamin wanita. Adapun jenis sapaan yang menunjuk ke dua jenis kelamin adalah sapaan yang bersifat netral seperti: ndara, gusti, yayi, adhi, raka, kata-kata ganti, dan nama diri. Kutipan yang mendukung bentuk tersebut dapat dilihat pada uraian berikut.

(20) Karna: ..ingkang Raka mboten ketang namung sakedheping netra, dinten menika ugi nyuwun pamit badhe wangsul dhateng Ngawangga, sedya pamit kaliyan ingkang raka Dewi Surtikanthi.

Karna: ..kakanda meskipun hanya selama mata berkedip, hari ini juga minta diri kembali ke Ngawangga, perlu berpamitan dengan kakakmu Dewi Surtikanthi.

Penggunaan sapaan raka pada kutipan (20) menunjukkan bahwa sapaan raka dapat menunjuk jenis kelamin laki-laki dan perempuan. Sistem ini berlaku pula pada kata sapaan ndara, gusti, yayi, dan adhi.

\section{c. Sistem dan Fungsi Sapaan yang Ditentukan oleh Aspek Setting}

Sistem sapaan yang ditentukan oleh aspek setting dibagi dalam tiga kriteria. Kriteria 
pertama adalah setting tempat, kedua setting waktu dan ketiga suasana. Sistem sapaan yang ditentukan oleh tempat menimbulkan sistem sapaan yang bersifat resmi dan santai. Sapaan yang bersifat resmi misalnya adegan yang digunakan dalam adegan kenegaraan seperti dalam janturan. Sapaan yang digunakan di dalam adegan janturan dipilih yang bersifat resmi yaitu sapaan para rakyat, punggawa kerajaan dan raja. Sapaan yang bersifat hubungan kerabat pada adegan tersebut agak dikesampingkan. Berikut ini kutipan sapaan dalam adegan janturan.

(21) Duryudana: Paman Sengkuni, mboya dados lukitaning penggalih pekenira, pekenira manira wenten majeng wenten ngarsa putra pekenira, paman paman Harya.

Duryudana: 'Paman Sengkuni, jangan menjadikan sedihnya hatimu, kamu aku panggil menhadap dihadapan ananda, paman paman Harya.'

Sapaan pada kutipan di atas adalah sapaan Duryudana yang menyapa patih Sengkuni dengan sapaan resmi yaitu pekenira . Patih Sengkuni menyebut dirinya dengan $a b d i$ dalem 'hambamu'. Sapaan yang digunakan dalam suasana resmi dan tempat resmi seperti ini tidak mungkin akan diganti dengan sapaan yang lain.

Setting waktu juga mempengaruhi seorang tokoh dalam memilih jenis sapaan. Jenis-jenis sapaan tersebut dapat dilihat pada kutipan berikut ini.

(22) Kartadendha: Eeee, huh huh Pamoan kula nungsung werta Man, Man.

Kartadendha: 'Eeee, huh huh Pamoan saya minta kabar Man, Man.'

(23) Wikathabala: Ana satriya ngaglak ana tengahing paprangan sapa he?

Wikathabala: "Ada satriya berdiri di tengah-tengah pertempuran siapa he?

Kutipan di atas yang menunjukan waktu dan suasana adegan alun-alun adalah kutipan (22), sedangkan kutipan (23) menunjukkan adegan di medan perang. Pemilihan jenis sapaan pada (23) terlihat lebih seenaknya dan tidak peduli dengan sopan santun. Berdasarkan contoh kutipan di atas jelas terlihat bahwa waktu dan suasana saling mengisi dalam menentukan aspek penentu sistem sapaan.

\section{d. Sistem dan Fungsi Sapaan yang Ditentukan oleh Aspek Penghormatan}

Sistem sapaan jenis ini pemilihannya didasari oleh aspek penghormatan. Jenis sapaan yang digunakan berupa sapaan penghormatan. Misalnya menyapa dengan gelar, jabatan, dan kata ganti honorifik atau kata ganti dalam tingkat krama inggil. Sapaan ini berfungsi untuk menghormati orang yang disapa. Perhatikan kutipan berikut ini.

(24) Semar: Mesthinipun ndara Janaka taksih enget sabdanipun keng eyang Sinuwun Prabu Maswapati.

Semar: 'Mestinya ndara Janaka masih ingat sabda kakekmu Sinuwun Prabu Maswapati.'

(25) Surtikanthi: Pepundhen kula wonten madya pada sang Adipati, kepareng kula nyaosaken pambagya raharja rawuh paduka,..

Surtikanthi: 'Orang yang sangat aku hormati dan aku ikuti di dunia sang Adipati, perbolehkanlah saya menyampaikan ucapan selamat datang atas kehadiran paduka,..'

(26) Maswapati: Putu Prabu Bathara Kresna padha kanthi.

Maswapati:' Cucu Prabu Bathara Kresna dengan..'

Sapaan pada kutipan-kutipan di atas dipilih atas dasar aspek penghormatan terhadap orang yang disapa. Pada kutipan (24) dipilih jenis sapaan penghormat berupa kata sapaan ndara' tuan'. Kata ini dipilih karena penyapa adalah berstatus abdi, sehingga harus menyapa dengan penghormatan terhadap majikannya. Pada kutipan (25) Surtikanthi menyapa suaminya dengan sapaan honorifik yang sangat panjang yaitu pepundhen kula wonten madya pada sang Adipati. Sapaan ini berfungsi untuk menunjukkan betapa Surtikanthi sangat 
hormat, tergantung dan patuh pada suaminya, sehingga suaminya adalah segala-galanya di dunia. Sapaan ini muncul karena konteks kultural bahwa tipe khas wanita Jawa yang sangat ideal adalah wanita yang patuh, setia dan menyegalakan suaminya seperti Surtikanthi tersebut. Adapun kutipan (26) adalah penghormatan seorang kakek yang berkedudukan raja terhadap cucu yang berkedudukan raja dan berkharisma dewa, maka sapaan yang dipilih adalah wayah Prabu Bathara Kresna. Kata bathara adalah penanda sapaan dewa, sedang letak penghormatan sapaan tersebut adalah penyebutan gelar dan titisan yaitu prabu dan bathara.

\section{e. Sistem dan Fungsi Sapaan yang Ditentukan oleh Aspek Pelaku/ Pekerjaan}

Sistem sapaan ini jenisnya menunjukkan ciri pelaku kerja atau profesi seseorang yang disapa. Jenis sapaan mengacu pada jenis karya yang dilakukan atau profesi orang yang disapa. Berikut ini contoh kutipannya.

(27) Gareng: slung slung, wah sing ngegong galak.

Gareng: slung slung, aduh penabuh gongnya galak.'

Sapaan pada kutipan (27) dipilih berdasarkan aspek profesi yaitu tukang gong. Sapaannya adalah sing ngegong, kata sing menujukkan orang dan kata ngegong menunjukkan perkerjaan orang yang disapa.

\section{PENUTUP}

Berdasarkan uraian hasil dan pembahasan di atas, dapat disimpulkan bahwa terbentuknya sistem sapaan dalam wayang kulit ditentukan oleh 12 aspek penentu hubungan. Adapun jenis sapaan yang terdapat dalam wayang kulit terdiri dari 28 jenis sapaan. Adapun fungsi sapaan dalam wayang kulit terdiri dari 11 fungsi. Selain hal-hal di atas, adalah jenis sapaan dewa, sapaan bagongan Hastina, dan sapaan honorifik untuk raja, permaisuri dan patih. Ciri khas sapaan bagongan Hastina terletak pada sapaan raja terhadap patih dan orang yang dihormati raja.

Bagi para peneliti lain disarankan untuk mengkaji cerita, gaya dan dalang yang berlainan, khususnya gaya yang berbeda, karena dengan ditelitinya gaya berbeda pasti akan ditemukan sistem, jenis dan fungsi sapaan yang dapat diharapkan akan melengkapi penelitian ini.

Ada hal yang dapat diambil pelajaran bagi pemerhati pakeliran dan para seniman wayang bahwa untuk menciptakan dan memahami watak khas tokoh-tokoh wayang, pencipta, dan penikmat harus mampu masuk ke dalam alur cerita dan mengandaikan dirinya sebagai penyapa dan yang disapa, dan tidak bisa sebagai penyapa atau yang disapa saja.

\section{DAFTAR PUSTAKA}

Chaica, Elaine. 1982. Language The Sosial Mirror. Rowley: Newbury House Publishers, Inc.

Crystal, David. 1980. A Dictionsry of Linguistics and Phonetics. Massachusetc: Basil Black Well.

Ervin-Tripp, Susan. 1972. On Sociolinguistic Rules: Alternation and Co-occurrence. Dalam Gumperz, John J. 1972. Directions In Sociolinguistics The Ethnography of Communication. New York: Holt, Rinehart and Winston, Inc.

Halliday, Ruqaiya Hasan. 1980. Text and Context dalam Asrudin Barori Tou. 1994. Bahasa Konteks dan Teks Aspekaspek Bahasa Dalam Pandangan Semiotik Soaial. Yogyakarta: Gadjah Mada University Press.

Kartomihardjo, Suseno. 1988. Bahasa Cermin Kehidupan Masyarakat. Jakarta: PPLPTK, Depdikbud.

Kridalaksana, Harimurti. 1984. Kamus Linguistk. Jakarta: Gramedia.

Mudjanattistomo, dkk. 1977. Pedhalangan Ngayogyakarta Jilid I. Ngayogyakarta: Yayasan Habirandha.

Sri Mulyono. 1989. Simbolisme dan Mistikisme dalam wayang. Jakarta: CV Haji Masagung. 
Supriyanto, Henricus. 1986. Bentuk Sapaan Bahasa Jawa Dialek Jawa Timur. Jakarta: Pusat Pembinaan dan Pengembangan Bahasa Departemen Pendidikan dan Kebudayaan.

Tannen, Deborah. 1996. Seni Komunikasi Efektif Membangun Relasi dengan membina Gaya Percakapan. Jakarta: Gramedia.

Wijana, I Dewa Putu. 1991. The of Term of Address in Bahasa Indonesia. Yogyakarta: Fakultas Sastra Universitas Gadjah Mada 